\title{
PENGARUH PEMBERIAN AIR KELAPA TERHADAP PERAKARAN ANGGREK KELINCI (Dendrodium antennatum Lindl.)
}

\section{(Additional Effect of Coconut Water towards the Rooting Development of Rabbit Orchid [Dendrodium antennatum Lindl.])}

\author{
Agustriani R. Warpur ${ }^{1}$ dan Inggrid N. Kailola ${ }^{1 凶}$ \\ Program Studi Biologi, Fakultas Sains dan Teknologi Universitas Ottow Geissler Papua. \\ Tlp/Fax: (0967)581562, 581133 \\ $\triangle$ Penulis Korespondensi: Email: Inggridnk@gmail.com \\ Diterima: 07 Jul 2017| Disetujui: 11 Agust 2017
}

\begin{abstract}
Abstrak
Penelitian ini bertujuan untuk mengetahui volume air kelapa yang paling sesuai untuk pertumbuhan tanaman anggrek kelinci (Dendrodiium antennatum Lindl.) Metode yang digunakan adalah eksperimental dengan menggunakan rancangan acak lengkap yaitu empat perlakuan dengan empat ulangan. Parameter yang diamati adalah panjang akar dan jumlah akar, yang selanjutnya data hasil kemudian dianalisis dengan analisis ragam dan uji lanjutan dengan uji BNJ. Hasil penelitian menunjukkan bahwa terdapat pengaruh pemberian air kelapa pada media perakaran anggrek kelinci (D. antennatum Lindl.). Air kelapa $300 \mathrm{ml}$ merupakan volume terbaik bagi pertumbuhan panjang akar dan jumlah akar anggrek dengan panjang akar 9,8 mm dan jumlah akar sebanyak 16 helai. Perlakuan air kelapa pada media perakaran berpengaruh terhadap panjang dan jumlah akar dimana $\mathrm{F}$ hitung yang dihasilkan dari masing-masing parameter lebih besar nilainya dari F table pada $\alpha$ 0.05. Maka volume air kelapa yang paling efektif untuk pertumbuhan tanaman anggrek kelinci (D. antennatum Lindl.) ialah $300 \mathrm{ml}$.
\end{abstract}

Kata kunci: Air kelapa, D. Antennatum, perlakuan, media tumbuh, in vitro.

\begin{abstract}
This study aimed to reveal the best appropriate volume of coconut water for accelerating the growth and elongation of Dendrodiium antennatum Lindl roots. Method that applied was experimental by way of treatments in four repetitions thorugh complete random desain formula approach. There were two parameters that observed such as root elongation and number of root presented. The result showed there was a positive correlation between coconut water addition and the growing and elongated root from D. Antennatum plant. The best volume of coconut water to maximize growth and length of D. antennatum was $300 \mathrm{ml}$ with the maximum length of $9,8 \mathrm{~mm}$ and number of roots was 16 strands. The treatment of coconut water towards rooted media was linerary correlated which has been indicated by $F$ value that surpassed $F$ value in table in the level of $\alpha 0.05$. Therefore, the best appropriate concentration volume for coconut water addition was $300 \mathrm{ml}$.
\end{abstract}

Keywords: Coconut water, D. Antennatum, treatment, growth media, in vitro. 


\section{PENDAHULUAN}

Indonesia terkenal sebagai negara yang memiliki banyak spesies anggrek alam. Diperkirakan setengah dari spesies ini terdapat di Papua, sementara 2.000 spesies lainnya terdapat di pulau Kalimantan dan sisanya tersebar di pulaupulau kecil lain di Indonesia. Saat ini pengembangan anggrek di Indonesia menghadapi berbagai masalah diantaranya penyediaan bibit yang terbatas, kualitas bibit yang masih rendah dan teknik budidaya yang belum dilakukan dengan baik (Andri dan Tumbuan 2015).

Perbanyakan tanaman secara vegetatif merupakan alternatif untuk mendapatkan tanaman baru yang mempunyai sifat sama dengan induknya dalam jumlah besar. Perbanyakan secara vegetatif dengan sistem konvensional, umumnya masih memerlukan waktu yang cukup lama. Oleh karena itu, saat ini dibeberapa negara maju telah banyak dikembangkan suatu sistem perbanyakan tanaman secara vegetatif yang lebih cepat dengan hasil yang lebih banyak lagi, yaitu dengan sistem kultur jaringan (Prasetyo 2009).

Teknik perbanyak in vitro merupakan salah satu usaha konservasi untuk mencegah kepunahan jenis $D$. antennatum Lindl. Teknik tersebut dapat menyediakan tanaman-tanaman baru anggrek alam secara cepat dengan kualitas dan kuantitas yang baik. Usaha meningkatkan produksi anggrek kelinci D. antennatul dengan teknik kultur in vitro secara kualitatif dan kuantitatif dapat digunakan dengan modifikasi media melalui penambahan persenyawaan organik kompleks sehingga dapat mengoptimalkan pertumbuhan $D$. antennatum. Salah satu bahan yang dapat dipakai untuk mengoptimal pertumbuhan tanaman ini adalah air kelapa. Air kelapa mengandung zat atau bahan-bahan seperti unsur hara, vitamin, asam amino, asam nukleat dan zat tumbuh seperti auksin dan asam giberelat yang berfungsi sebagai penstimulasi proliferasi jaringan, memperlancar metabolisme dan respirasi (Utari 2006). Pemberian air kelapa pada pembuatan media Knudson $\mathrm{C}$ mampu menstimulasi pembelahan sel dan pertumbuhan anggrek.

Berdasarkan uraian di atas, maka tujuan dari penelitian ini ialah untuk membandingkan beberapa volume air kelapa guna mendapatkan formulasi yang efektif terhadap pertumbuhan planlet anggrek $D$. antennatom Lindl, dan diharapkan dapat memberikan pengaruh terhadap pertumbuhan planlet anggrek kelinci pada kultur jaringan di wilayah Jayapura.

\section{METODE PENELITIAN}

\section{Gambaran Umum Penelitian}

Penelitian ini dilaksanakan selama dua bulan yaitu Februari hingga Maret 2017 pada Laboratorium Kultur Jaringan Biologi FMIPA, Universitas Cenderawasih. dengan bahan dan peralatan pendukung antara lain planlet anggrek D. antennatum Lindl, yang berasal dari tahapan multiplikasi pada Laboratorium Kultur Jaringan Waena, autoklaf, hot plate, pengaduk magnetik, timbangan analitik, laminar air flow cabinet (LAFC), kamera digital, petridisc, pinset, jangka sorong, erlenmeyer, pipet ukur, pipet tetes, gelas beker, botol kultur, hand sprayer, kertas label, karet gelang, almunium foil dan alat tulis dan kapas. 


\section{Metode dan Rancangan}

Metode yang digunakan dalam penelitian ini adalah: metode eksperimen dan metode deskriptif. Sementara rancangan penelitian yang digunakan adalah Rancangan Acak Lengkap (RAL) yang terdiri dari 5 perlakuan dan masingmasing perlakuan akan diulang sebanyak 5 kali, sehingga dengan demikian akan diperoleh 20 satuan percobaan.

Perlakuan yang digunakan dalam penelitian ini menurut (Pongmangallo 2011) adalah sebagai berikut:

$\mathrm{K}_{0} \quad=$ sukrosa 10 gram, 4 kali

(kontrol) pengulangan

$\mathrm{K}_{1}=$ sukrosa 10 gram + air kelapa $100 \mathrm{ml}, 5$ kali pengulangan

$\mathrm{K}_{2}=$ sukrosa 10 gram + air kelapa $200 \mathrm{ml}, 5$ kali pengulangan

$\mathrm{K}_{3}=$ sukrosa 10 gram + air kelapa $300 \mathrm{ml}, 5$ kali pengulangan

Dengan ulangan sebanyak 5 ulangan yaitu $A_{1}, A_{2}, A_{3}, A_{4}, A_{5}$.

Sementara prosedur umum penelitian yang dilakukan antara lain: sterilisasi alat dan lingkungan kerja atau laboratoriun guna sterilisasi bahan penelitian sebelum dilakukan analisis; pembuatan larutan stok; setelah itu dilanjutkan dengan pembuatan media perakaran; dan dilanjutkan lagi dengan proses transplant bibit anggrek; dan pada akhrnya dilakukan pengukuran sampel guna melihat perubahan respon tanaman anggrek terhadap perlakuan media tumbuh. Dalam penelitian ini parameter utama yang dilihat yaitu penambahan dimensi panjang akar baru dan jumlah kehadiran akan tanaman anggrek.

\section{Analisis Data}

Data yang diperoleh dari hasil pengamatan sesuai parameter, selanjutnya akan diolah secara stastistik mengunakan analisis ragam Anova One Wey. Apabila terdapat pengaruh yang berbeda nyata pada berbagai perlakuan terhadap kontrol, maka akan dilanjutkan dengan Uji Beda Nyata Jujur (BNJ) pada taraf kepercayaan a 0,05 (Yitnosurmarto 1993).

\section{HASIL DAN PEMBAHASAN}

\section{Panjang akar}

Hasil analisis ragam panjang akar diperoleh nilai $\mathrm{F}$ hitung yang merupakan nilai $F$ dari hasil perhitungan analisis adalah 3,546886 yang mana lebih besar dari $\mathrm{F}$ tabel yaitu merupakan dengan nilai 3,47805 pada taraf kepercayaan $95 \%$. Hal ini menunjukan bahwa air kelapa berpengaruh nyata terhadap panjang akar dapat dilihat pada tabel 1 .

Tabel 1. Hasil analisis statistik parameter panjang akar tanaman anggrek

\begin{tabular}{lccccc}
\hline $\begin{array}{c}\text { Sumber } \\
\text { keragaman }\end{array}$ & $\mathrm{Db}$ & $\begin{array}{c}\text { Jumlah } \\
\text { kuadrat }\end{array}$ & $\begin{array}{l}\text { Jumlah } \\
\text { tengah }\end{array}$ & F Hitugan & F Tabel \\
\hline Perlakuan & 4 & 388645,8 & 0,047506 & 3,546886 & 3,47805 \\
Galat & 10 & 109573,8 & & & \\
Total & 14 & & & & \\
\hline
\end{tabular}


Sitokin yang terdapat dalam air kelapa berfungsi memacu pembelahan sel dan pembentukan organ, menunda penuaan, memacu pertumbuhan kuncup samping tumbuhan dikotil, memacu perkembangan kloroplas dan sintesis klorofil. Sitokinin merangsang pembelahan sel melalui peningkatan laju sistensis protein. Sitokin berkerja sama dengan auksin berperang penting dalam morfogenesis tumbuhan dengan memacu pembentukan akar dan tunas (Inayah 2016). Sementara menurut Djajanegara (2010), selain asam amino air kelapa juga mengandung asam organik, asam nukleotida, purin, gula, gula alkohol, vitamin (thiamin, asam ascorbat, dll.), zat pengatur tumbuh dan mineral yang penting bagi pertumbuhan tanaman. Sukrosa merupakan kandungan sukrosa tertinggi yang terdapat dalam air kelapa.

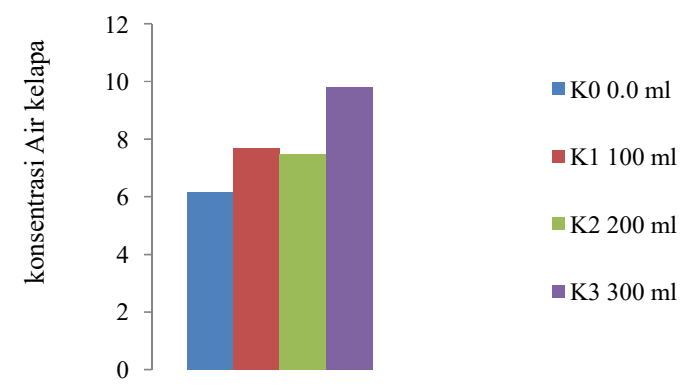

Gambar 1. Perbandingan komposisi konsentrasi air kelapa terhadap laju pertumbuhan panjang akar tanaman anggrek

Pada gambar 1 terlihat perlakuan pada media Khudson dengan mengunakan air kelapa sebagai pengganti sukrosa. Hasil analisis menunjukkan bahwa pengunaan air kelapa dengan volume $0,0 \mathrm{ml} / \mathrm{l}$ mendapatkan panjang akar rata-rata 6,16 $\mathrm{mm}$. Demikian pula dengan penambahan air kelapa $100 \mathrm{ml} / \mathrm{l}$ dengan panjang akar adalah 7,7 mm. Penambahan air kelapa $200 \mathrm{ml} / 1$ panjang akarnya mencapai 7,5 $\mathrm{mm}$ yang kemungkinan dikarenakan terjadiya kontaminasi. Sedangkan penambahan air kelapa $300 \mathrm{ml} / 1$ diperoleh hasil panjang akar mencapai 9,8 $\mathrm{mm}$ dan merupakan proporsi volume air kelapa terbaik. Air kelapa baik digunakan pada media kultur jaringan karena mengandung zat atau bahan-bahan seperti vitamin, mineral, asam-asam amino dan asam nukleat, fosfor serta zat tumbuh auksin dan giberelat yang berfungsi sebagai penstimulir proliferasi jaringan, memperlancar metabolime respirasi (Tuhuteru dkk. 2012).

Dalam kultur jaringan, auksin yang terdapat pada air kelapa berperan memacu pembentukan kalus, menghambat kerjasitokinin, membentuk klorofil dalam kalus, mendorong proses morfogenesis kalus, membentuk akar, dan mendorong proses embriogenesis. Sitokinin berperan memacu pembelahan sel, proliferasi meristem ujung, menghambat pembentukan akar, dan mendorong pembentukan klorofil pada kalus (Suracman 2011). Air kelapa selain 
mengandung hormon tumbuh auksin dan sitokin, juga mengandung nutrisi yang dibutuhkan oleh tanaman. Pada volume air kelapa $300 \mathrm{ml}$ memberikan dampak ketersediaa nnutrisi yang lebih baik jika dibandingkan dengan jumlah pemberiaan air kelapa dalam volume yang lebih sedikit. Ketersediaan nutrisi bagi tanaman sangat penting untuk proses pertumbuhan. Dengan adanya unsur kalium (K) yang tinggi, maka air kelapa dapat merangsang pertumbuhan dengan cepat (Tiwery 2014).

\section{Jumlah Akar}

Hasil analisis ragam jumlah akar diperoleh nilai $\mathrm{F}$ hitung sebesar 2,196647 yang mana lebih besar dari pada $F$ tabel (uji F) senilai 3,47805 pada taraf kepercayaan 95\%. Hal ini menunjukkan bahwa air kelapa berpengaruh nyata terhadap jumlah akar dapat di lihat pada tabel berikut 2 di bawah ini.

Tabel. 2. Hasil analisis statistik parameter jumlah akar tanaman anggrek

\begin{tabular}{lcrrrr}
\hline $\begin{array}{c}\text { Sumber } \\
\text { Keragaman }\end{array}$ & $\mathrm{Db}$ & $\begin{array}{c}\text { Jumlah } \\
\text { kuadrat }\end{array}$ & $\begin{array}{c}\text { Jumlah } \\
\text { tengah }\end{array}$ & $\begin{array}{c}\mathrm{F} \\
\text { Hitungan }\end{array}$ & F Table \\
\hline Perlakuan & 4 & 191016,4 & 0,142664 & 2,196647 & 3,47805 \\
Galat & 10 & 86958,2 & & & \\
Total & 14 & & & & \\
\hline ** & & & & &
\end{tabular}

**Berpengaruh nyata pada taraf 0,05

Menurut Kasutjianingati (2013) di dalam air kelapa terkandung hormon sitokinin 5,8 mg/l, auksin 0,07 mg/l dan giberalin yang dapat menstimulasi perkecambahan dan pertumbuhan tanaman dan berfungsi sebagai penstimulir dalam proliferasi jaringan, memperlancar metabolisme dan respirasi. Oleh karena itu air kelapa mempunyai kemampuan besar untuk mendorong pembelahan sel dan proses deferensiasi. Kandungan sukrosa dalam air kelapa yang ditambahkan dalam media sudah cukup sebagai sumber energi bagi pertumbuhan dan perkembangan jaringan yang dikulturkan (Djajanegara 2010).

Pembentukan akar dipengaruhi oleh keseimbangan kandungan sitokinin dan auksin, komposisi hormon yang sesuai maka pertumbuhan akar dari stek tidak terhambat. Senyawa lain yang terdapat dalam air kelapa adalah protein, lemak, mineral, karbohidrat, bahkan lengkap dengan vitamin $\mathrm{C}$ dan kompleks. Protein dan karbohidrat dibutuhkan tanaman sebagai cadangan makanan, lemak dibutuhkan tanaman sebagai cadangan energi, mineral sebagaibahan penyusun tubuh tanaman, dan vitamin $\mathrm{C}$ dan $\mathrm{B}$ kompleks berperan di dalam proses metabolisme.

Pada gambar 2 perlakuan pada media Khudson $\mathrm{C}$ dengan mengunakan air kelapa sebagai penganti sukrosa. Hasil penelitian menunjukkan bahwa pengunaan air kelapa dengan konsentrasi $0,0 \mathrm{ml} / 1$ mendapatkan hasil jumlah akar sebanyak 8 helai. Demikian pula pada air kelapa $100 \mathrm{ml} / 1$ jumlah akar sebanyak 10 helai dan pengunaan air kelapa $200 \mathrm{ml} / 1$ memperoleh jumlah akar sebanyak 13 helai. Selanjutnya pengunaan air kelapa $300 \mathrm{ml} / 1$ diperoleh hasil jumlah akar yaitu sebanyak 16 helai dan merupakan volume terbaik dengan jumlah akar terbanyak. 


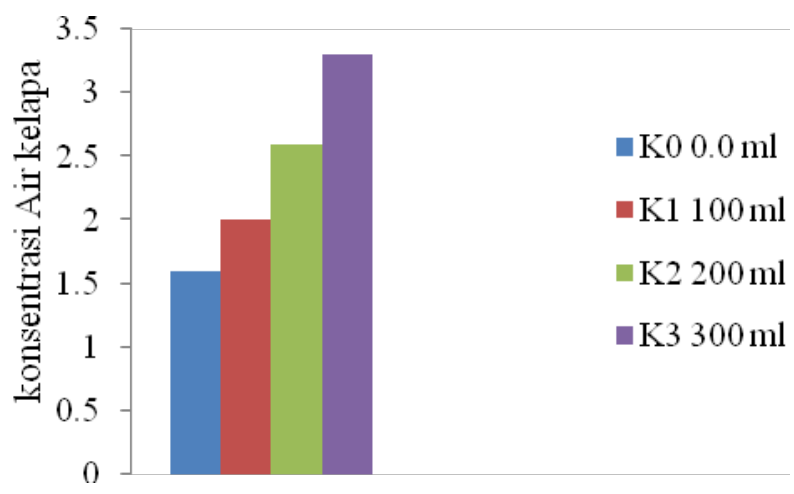

Gambar 2. Perbandingan komposisi konsentrasi air kelapa terhadap kehadiran jumlah akar tanaman anggrek

Air kelapa merupakan endosperm atau cadangan makanan cair sumber energi, selain mengandung auksin dan sitokinin adalah senyawa paling penting dalam mengatur pertumbuhan dan morfogenesis pada kulturin vitro (Fauzan 2011). Kandungan sitokinin yang terdapat dalam air kelapa juga memiliki peran alam pembentukan akar. Sitokinin yang terkandung dalam air kelapa mempunyai kemampuan mendorong terjadinya pembelahan sel dan diferensiasi jaringan terutama dalam pembentukan tunas dan pembentukan akar (Latifah 2017).

\section{Hasil Panjang akar dan Jumlah akar}

Hasil perhitungan panjang dan jumlah akar pada Tabel 3. menunjukkan bahwa pemberian air kelapa 300 gr merupakan kombinasi terbaik dalam memacu pertumbuhan akar dan daun dengan panjang akar 9,8 mm, jumlah akar 16 helai. Menurut Mukminin (2016) yang mengatakan bahwa air kelapa muda merupakan suatu cairan yang mengandung unsur hara dan ZPT sehingga dapat menstimulasi perkecambahan dan pertumbuhan. Air kelapa merupakan salah satu di antara beberapa persenyawaan kompleks alamiah yang sering digunakan dalam kultur jaringan untuk perbanyakan mikro anggrek. Penggunaan air kelapa sebagai bahan organik merupakan salah satu cara untuk mengantikan penggunaan bahan sintetis yang dipakai dalam pembuatan media kultur, seperti kinetin (Tuhuteru dkk.2012).

Tabel 3. Kombinasi perlakuan terhadap hasil analisis pertambahan panjang dan jumlah akar tanaman anggrek

\begin{tabular}{cccc}
\hline No. & Perlakuan & $\begin{array}{c}\text { Panjang Akar } \\
(\mathrm{mm})\end{array}$ & Jumlah Akar \\
\hline 1. & K0 & 6,16 & 8 \\
2. & K1 & 7,7 & 10 \\
3. & K2 & 7,5 & 13 \\
4. & K3 & 9,8 & 16 \\
\hline
\end{tabular}


Pemberian air kelapa $150 \mathrm{ml} / \mathrm{l}$ ditambah sukrosa $20 \mathrm{gr} / \mathrm{l}$ dalam media kultur memberikan hasil terbaik terhadap protocorm like bodies (plbs) anggrek dendrodium (Djajanegara 2010). Hasil penelitian ini menunjukkan bahwa $300 \mathrm{ml}$ air kelapa dan 10 gr sukrosa juga efektif untuk meningkatkan pertumbuhan planlet anggrek $D$. antennatum Lindl. Mengingat 10 gr sukrosa lebih murah dibandingkan 20 gr sukrosa, disamping itu juga kelapa (air kelapa) banyak terdapat di Indonesia yang mudah diperoleh sehingga bisa menganti 20 gr sukrosa, sebagai sumber energi dalam media kultur jarigan (Tuhuteru dkk. 2012).

\section{DAFTAR PUSTAKA}

Andri KB dan Tumbuan WJFA. 2015. Potensi pengembangan agribisnis bunga anggrek di kota Batu Malang Jawa Timur. Jurnal LPPM Bidang EkoSosBudKam, Vol 2 (1): 19-30.

Djajanegara. 2010. Pemanfaatan limbah buah pisang dan air kelapa sebagai bahan media kultur jaringan anggrek bulan (Phalaenopsis amabilis) tipe 229.

Fauzan MAH. 2011. Perbandingan air siwalan dan air kelapa sebagai suplemen pada media VW (vacin dan went) kultur jaringan anggrek bulan (Phalaenopsis amabilis). Malang.

Inayah M. 2016. Pemberian air kelapa dan ekstrak pisang raja terhadap kecambah biji dan perkembangan tunas embrio anggrek dendrobium lasianthera.

Kasutjianingati RI. 2013. Media alternatif perbanyakan in vitro anggrek bulan (Phalaenopsis amabilis). Jurnal Agroteknos, Vol 3 (3): 184-189.
Latifah R. 2017. Optimasi pertumbuhan plantlet cattleya melalui kombinasi kekuatan media murashige-skoo dan bahan organik. Politeknik Negeri Jember.

Mukminin HL. 2016. Pengaruh pemberian giberelin dan air kelapa terhadap perkecambahan biji anggrek bulan (phalaenopsis sp). Universitas Negeri Malang.

Pongmangallo NC. 2011. Pengaruh pemberian konsentrasi ekstrak ubi kayu pada media perakaran planlet Dendrodium violaceoflavens. Universitas cendarawasih Jayapura.

Prasetyo CH. 2009. Teknik kultur jaringan anggrek Dendrobium sp. di pembudidayaan anggrek widorokandang Yogyakarta (Skripsi). Surakarta: Universitas Sebelas Maret.

Suracman D. 2011. Teknik pemanfaatan air kelapa untuk perbanyakan nilam secara in vitro. Bogor.

Tiwery RR. 2014. Pengaruh penggunaan air kelapa (Cocos nucifera) terhadap pertumbuhan tanaman sawi (Brassica juncea L.). Biopendix, Vol 1 (1): 8694.

Tuhuteru S, Hehanussa ML dan Raharjo SHT. 2012. Pertumbuhan dan perkembangan anggrek Dendrobium anosmum pada media kultur in vitro dengan beberapa konsentrasi air kelapa. Agrologia,Vol 1 (1): 1-12. 2012

Utari R. 2006. Pengaruh bahan organik dan NAA terhadap pertumbuhan Anggrek hitam (Coelogyne pandurata) dalam kultur in vitro.

Yitnosumarto. 1993. Percobaan rancangan, Analisis dan Interprestasinya. Gramedia Pustaka Utama. 